\title{
A Critical Review of Digital Marketing: Effect of Flow and Impulse Buying
}

\author{
Rahmawati Azizah $\mathbf{M t}^{\mathbf{1}^{*}}$, Ria Octavia ${ }^{2}$ \\ ${ }^{12}$ Sekolah Tinggi Ilmu Ekonomi Al-Madani, Indonesia \\ 1rahma.azizah@almadani.ac.id, ${ }^{1}$ ria.octavia@almadani.ac.id \\ *corresponding author
}

\begin{abstract}
This study aims to examine the influence of user belief on flow, willingness to buy on flow, and flow on impulse buying behavior. The subjects of this research include Students/College Students, Civil Servants, Private Employees, Lecturers/Teachers, Professionals (accountants, consultants, etc.). The technique used is non-probability sampling, purposive sampling, with a total sample of 300 respondents aged 17 to 45 and are users of the digital application, Shopee, in Indonesia. The research instrument was an online questionnaire and was analyzed using multiple linear regression analysis. The results of this study showed that the dimension of the perceived usefulness of user belief has a positive effect on flow. Willingness to buy has a positive effect on flow and flow has a positive effect on impulse buying. Meanwhile, the ease of use dimension of the user belief variable has no positive effect on flow.
\end{abstract}

Keywords: flow, willingness to buy, user belief, impulse buying behavior.

\section{Tinjauan Kritis Pemasaran Digital: Pengaruh Flow dan Pembelian Impulsif}

\begin{abstract}
Abstrak
Penilitian ini bertujuan untuk menguji pengaruh kepercayaan pengguna (user belief) terhadap flow, willingness to buy terhadap flow, dan flow terhadap perilaku pembelian spontan. Subjek penelitian ini meliputi Pelajar/Mahasiswa, PNS, Karyawan Swasta, Dosen/Guru, Profesional (akuntan, konsultan, dll). Teknik yang digunakan adalah non-probability sampling dengan jenis purposive sampling dengan kriteria usia 17 hingga 45 tahun dengan total sampel 300 responden dan merupakan pengguna aplikasi digital Shopee di Indonesia. Instrumen penelitian ini adalah kuesioner yang dibuat secara daring dan dianalisis dengan menggunakan analisis regresi linier berganda. Hasil penelitian ini menemukan bahwa dimensi manfaat yang dirasakan dari kepercayaan pengguna berpengaruh positif terhadap flow, willingness to buy berpengaruh positif terhadap flow dan flow berpengaruh positif terhadap pembelian spontan. Sedangkan, dimensi kemudahan menggunakan dari variabel kepercayaan pengguna tidak berpengaruh positif terhadap flow.
\end{abstract}

Kata kunci: flow, willingness to buy, kepercayaan pengguna, perilaku pembelian spontan.

\section{INTRODUCTION}

The development of the digital world has changed many people's behaviors today, one of which is the use of increasingly sophisticated digital technology with the support of the internet as a medium for online shopping, which previously, was only done offline, by directly visiting shopping centers, but it is different now. The shift and change in purchasing behavior from offline to digital make consumers feel facilitated and spoiled by the sophistication of smartphones that have various service features and digital platforms 
in online shopping. Digital marketing is a way of promoting a brand, product, or service using digital media with the online marketing category to reach consumers on target according to consumer desires (Pangestika, 2018). This makes the distance between sellers and buyers is no longer a problem and a barrier in buying and selling transactions through digital platforms supported by communication technology (Pangestika, 2018).

Digital marketing has become an important part of any communication and interaction strategy between sellers and buyers because of its ability to provide various information about the brand or product being marketed as well as entertainment, and forums for online purchases (Richard, Chebat, Yang, \& Putrevu, 2010). People nowadays spend more time using the internet with digital applications both to access information (Ho et al., 2012) and to shop online (C. Hsu, Chang, \& Chen, 2012).

In 2018, Daily Social and JakPat surveyed 2,026 respondents throughout Indonesia to see how many consumers using digital platforms. The survey results showed that Shopee is one of the most frequently used e-commerce services by respondents in Indonesia (34\%), followed by Tokopedia (28\%), Bukalapak (17.5\%), Lazada (14\%) and Blibli (2.15\%) (Yusra dan Yenny, 2018).

Table 1. Assessment of Online Shopping Platforms in Indonesia

\begin{tabular}{lrrrrrr}
\hline & Blibli.com & Bukalapak JD.ID & Lazada & Shopee & Tokopedia \\
\hline Good reputation & $14.8 \%$ & $13.0 \%$ & $12.9 \%$ & $13.7 \%$ & $10.9 \%$ & $14.3 \%$ \\
Cheaper product price & $6.5 \%$ & $15.1 \%$ & $11.0 \%$ & $13.5 \%$ & $18.0 \%$ & $13.3 \%$ \\
More product selection & $6.5 \%$ & $14.6 \%$ & $5.2 \%$ & $11.3 \%$ & $13.0 \%$ & $16.8 \%$ \\
Authentic products & $13.9 \%$ & $3.9 \%$ & $19.5 \%$ & $7.2 \%$ & $4.2 \%$ & $4.3 \%$ \\
Good customer service & $12.0 \%$ & $8.9 \%$ & $5.2 \%$ & $6.5 \%$ & $7.7 \%$ & $8.8 \%$ \\
Fast delivery & $7.4 \%$ & $6.0 \%$ & $8.6 \%$ & $10.0 \%$ & $7.6 \%$ & $5.8 \%$ \\
Free delivery & $13.0 \%$ & $6.8 \%$ & $14.8 \%$ & $10.6 \%$ & $18.4 \%$ & $3.2 \%$ \\
Easy return policy & $6.5 \%$ & $5.7 \%$ & $2.9 \%$ & $5.4 \%$ & $4.5 \%$ & $5.3 \%$ \\
Easy navigation on site & $4.6 \%$ & $7.0 \%$ & $3.3 \%$ & $3.8 \%$ & $3.5 \%$ & $9.3 \%$ \\
More payment options & $9.3 \%$ & $8.9 \%$ & $11.0 \%$ & $13.4 \%$ & $5.3 \%$ & $8.4 \%$ \\
Better mobile app & $4.6 \%$ & $9.6 \%$ & $5.7 \%$ & $4.4 \%$ & $6.8 \%$ & $9.4 \%$ \\
Loyalty program & $0.0 \%$ & $0.3 \%$ & $0.0 \%$ & $0.0 \%$ & $0.1 \%$ & $0.0 \%$ \\
More promo & $0.9 \%$ & $0.0 \%$ & $0.0 \%$ & $0.0 \%$ & $0.2 \%$ & $0.9 \%$ \\
More secure & $0.0 \%$ & $0.3 \%$ & $0.0 \%$ & $0.1 \%$ & $0.0 \%$ & $0.2 \%$ \\
\hline
\end{tabular}

In 2018, EcommerceIQ surveyed 1,240 online shopping user respondents who discussed several factors assessing online shopping platforms, ranging from reputation, price comparison, to logistics services. The survey results showed that digital platform, Shopee,gets the most value in the cheap goods category with $18 \%$ and $18.4 \%$ for free shipping (Eka, 2018). 


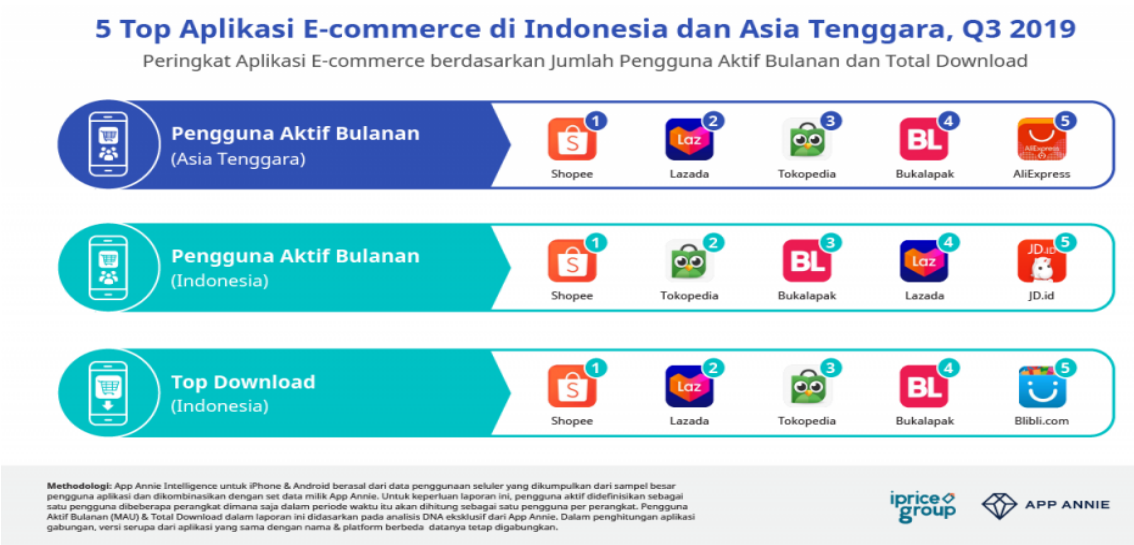

Figure1. E-commerce Competition Map in Indonesia Q3 2019

Source: iprice group and App Annie

Researcher used Shopee as the research object because, according to the data obtained from iPrice and App Annie, Shopee was ranked the first in Indonesia as a digital application which was previously ranked second after Tokopedia. Figure 1 shows that for the first time, Shopee has become the digital application with the highest number of

visitors in the third quarter of 2019. This was based on their cashback campaign strategy,

free delivery without minimum purchases, and the selection of their brand ambassadors from well-known people who are close to Shopee users resulting in their users feeling comfortable using it.

From the categories of active users and shopping downloads, most users or product buyers on the shopping application, Shopee,are Millennial buyers who are the target market for online sales. Buyers or Users in Indonesia are more active with digital online shopping applications on weekdays and are most active during the day from 11 am to 2 pm and at night from 8 pm to $9 \mathrm{pm}$.

Several studies related to online purchasing have been discussed by previous researchers (Hsu et al., 2012; Hsu, Chang, Kuo, \& Cheng, 2016; Lee \& Wu, 2017; Wei, Ma, \& Chen, 2017; Nata \& Sukaris, 2018; Ozkara, Ozmen, \& Kim, 2017; Zhou, Li, \& Liu, 2010; Zhou, 2012). A study (Novak \& Hoffman, 1996) stated that if the commercial sites can increase their consumer's desire to take action purchase ( willingness to buy ), it depends on their ability to provide the consumers with the experience of something that flows (flow). Flow occurs when an individual performs activities fully, is immersed in their activities and focuses their attention on these activities with total involvement (Csikszentmihalyi, 1975).

The ease of using a digital platform via mobile phone leads consumers to believe in a certain virtual store. Trust is built by utilizing effective communication media in the form of cheap discounts, free shipping, claims for damaged goods, as well as active marketing communication, where consumers are exposed to digital marketing communications, thereby increasing consumer purchasing opportunities for products spontaneously or impulse buying (Wei et al., 2017). 
Previous research (Csikszentmihalyi, 1975) stated that flow experience can provide a new framework for understanding consumer behavior in social environments when using computers or smartphones. This statement has attracted the attention of researcher to study consumer behavior so that some flow experience-based consumer research has increased.

Previous researches examined the flow experience and purchase intention (Hsu et al., 2012; Lee \& Wu, 2017) and online browsing activity and trust (Nata \& Sukaris, 2018). Meanwhile, the variable willingness to buy or the desire to buy and impulse buying behavior have not been tested simultaneously, thus, the researcher tries to simultaneously test the user belief constructs which uses two dimensions, namely the perceived usefulness and ease of use, willingness to buy or the desire to buy and flow experience to impulse buying (Nata \& Sukaris, 2018). Then, according to (Nata \& Sukaris, 2018) the factors that influence the buying impulse buying behavior onconsumers have rarely been investigated more deeply.

The objective of this study is to examine the influence of the perceived usefulness of the user belief to flow experience dimension, to examine the influence of ease of use of user belief against flow experience dimension, to examine the influence of willingness to buy against the flow, and to examine the influence of flow experience of the impulse buying behavior.

Research by (C. L. Hsu, Chang, Kuo, \& Cheng, 2016) entitled "The mediating effect of flow experience on social shopping behavior" discussed the relationship between four dimensions that focus on the experience of flow mediating social shopping behavior: user belief; website quality, including information quality, system quality, and service quality; flow experience, and social shopping behavior, that online marketing is in high demand nowadays and is becoming more and more important for business activities.

Previous research (Csikszentmihalyi, 1975) discussed the relationship between experience flow and online shopping behavior moderated by consumer characteristics (tend to believe, willingness to buy, and self-confidence). The results of this study indicated that the experience of flow has a positive and significant effect on buying behavior via the internet, moderated by some of these consumer characteristics.

Furthermore, research by (M. K. Chang, Cheung, \& Tang, 2013)) examined the flow experience of consumers in an online shopping environment and used online consumer participants to test how consumers explore the value of both hedonic and utilitarian shopping on links which in turn affected their satisfaction and unplanned purchase. His findings in this study indicated a positive effect.

Trust or user belief is the availability of a person to depend on the competence of other parties and the belief that the party is reliable (Koufaris, 2002). Trust is closely related to the perceived risk of purchasing, the more someone has high trust in virtual stores and certain brands, the lower the risk perception faced, which makes a person's attitude towards exploring an online store higher.

The effect of willingness to buy toward flow (C. Hsu et al., 2012) shows that individuals are more likely to shop in certain applications and buy a brand when their 
desire to buy online is very strong. In particular, when someone wants to buy a certain brand, it allows them to flow thereby, hence, increasing the amount of time spent browsing on certain digital applications (Wang, Hernandez, \& Minor, 2010).

The influence of Flow on Impulse Buying is a positive emotional response from consumers allowing it to facilitate spontaneous buying. In the context of online shopping, if consumers enjoy their shopping experience, they can undertake more exploratory browsing on online platforms via smartphones, leading to more impulsive or spontaneous purchases (Koufaris, 2002). Furthermore, in SOR theory, when experience flow occurs, an individual is fully focused on his activity in the search for a brand. Consumers who can focus their attention on online stores are more likely to pay attention to digital marketing promotions (Pangestika, 2018). So, when someone focuses on exploring information related to the brand they want to buy, they will create their own experience and direct consumers to impulse buying.

\section{Impulse Buying (Spontaneous Purchase)}

The basic framework of impulse buying begins with research by (Stern, 1962), where the purchase behavior is classified into three: planned, unplanned, and spontaneous (impulse). A planned purchase requires information searching and rational analysis which takes a longer time. Otherwise, an unplanned purchase does not require any planning. Differs from the unplanned purchase, a spontaneous purchase (impulse buying) usually requires quick decision-making. In spontaneous purchase (impulse buying), things that influence the desire of consumers to buy are something so sudden, powerful, and irresistible (Stern, 1962; Sundstrom et al., 2013).

Impulse buying is also defined as a purchase that occurs when someone sees a product, suddenly wants to buy it, then decides to buy it,the actions someone takes without having a prior plan is formed before entering both offline and online stores.

\section{Flow}

Flow is defined as the sensation of the deep experience felt by consumers as a whole when they are in a state of total involvement (Csikszentmihalyi, 1975; Hsu et al., 2016). Research by (C. Hsu et al., 2016) stated that when consumers achieve such state, their experience (flow) increases their motivation to use the internet and has an influence on their attitudes and behavior in the online shopping process. When consumers feel the flow condition, they will be immersed in fun activities, with awareness focused on surfing the internet, they feel they have complete control over the environment around them.

\section{SOR Theory (Stimulus-Organism-Response Theory)}

According to (Wang et al., 2010), the shopping environment contains a very strong stimulus (S) that affects the organism or a consumer $(\mathrm{O})$ and generates a behavioral response leading to closer action or avoidance $(\mathrm{R})$ towards online and offline stores such as shop searching, intention to buy, and repurchase intention. The study also discussed environmental cues (color, lighting, music, fragrances, layout, discounts), the influence of 
internal customer circumstances, and external responses in an online retail store environment.

\section{The Influence of User Belief on Flow Experience}

Previous research has identified a positive relationship between ease of use and the perceived usefulness of the flow experience (C. Hsu et al., 2016). Trusts or user belief is the availability of a person to depend on the competence of other parties and the belief that the party is reliable (M. K. Chang et al., 2013). Trust is closely related to the perceived risk of purchasing, the more someone has high trust in virtual stores and certain brands, the lower the risk perception faced, which makes a person's attitude towards exploring an online store higher.

The user believes reflects user confidence in its ability to provide mobile services, integrity, which in turn affects a person's experience of the product at the service provider, which is purchased if the user trusts the mobile service provider (Zhou et al., 2010). Then, (Csikszentmihalyi, 1975) stated that flow can increase when an individual considers an activity to be easy to do. In other words, perceived ease of use can be associated with perceived pleasure, the easier the online system to use, the more fun it is to do $(\mathrm{H}$. Chang \& Wang, 2008). Based on the thinking framework above, the $\mathrm{H} 1$ hypothesis is formulated as follows:

H1a: The dimension of the perceived usefulness of user belief has a positive effect on the flow experience

H1b: The ease of use dimension of user belief has a positive effect on the flow experience

\section{The Influence of Willingness to Buy on Flow Experience}

The effect of willingness to buy toward flow (C. Hsu et al., 2012) shows that individuals are more likely to shop in certain applications and buy a brand when their desire to buy online is very strong. In particular, when someone wants to buy a certain brand, it allows consumers to flow thereby, hence, increasing the amount of time spent browsing on certain digital applications (Novak \& Hoffman, 1996). Based on the mentioned above framework, the $\mathrm{H} 2$ hypothesis is formulated as follows:

H2: willingness to buy has a positive effect on flow.

\section{The Effect of Flow Experience towards The Unplanned Purchase (impulse buying)}

The effect of flow on impulse buying is a positive emotional response from consumers allowing it to facilitate unplanned purchases (C. Hsu et al., 2012). In the context of online shopping, if consumers enjoy their shopping experience, they can undertake more exploratory browsing on online platforms via smartphones, leading to more impulsive or spontaneous purchases (Koufaris, 2002).

Besides, in SOR theory, when a flow experience occurs, an individual is fully focused on his activity in the search for a brand. Consumers who can focus their attention on online stores are more likely to pay attention to digital marketing promotions (Pangestika, 2018). Thus, when someone who focuses on exploring information related to 
the brand you want to buy will create a separate experience and direct consumers to spontaneous purchases (impulse buying) (C. Hsu et al., 2016). Based on the above thought framework, the $\mathrm{H} 3$ hypothesis is formulated:

H3: flow positively affects impulse buying

\section{METHOD}

The research uses the quantitative approach. In distributing questionnaires and data collection, researcher utilized the help of google form or google doc which was taken place in Bandar Lampung, Lampung, Indonesia. The sampling technique used was a nonprobability sampling, purposive sampling (Cooper and Schindler, 2014) with certain criteria of respondents must be a user of the digital application, Shopee, in Indonesia and never made unplanned spontaneous purchases with a range of ages between 17 and 45 .

The subjects of this study include students, civil servants/ASN, private employees, lecturers/teachers, professionals (accountants, consultants, doctors), and others. Shopee was launched to reach middle-class users, whose average level of expenditure is not that high and is reachable toteenage or millennial consumers. Therefore, researcher selected and used a variety of professions as a sample of respondents. Another reason for choosing and using several professions as a sample of respondents is because they often browse and explore Shopee only to see information related to discounts, entertainment for playing games, and shopping.

In taking the sample, researcher followed the sample size from (Hair et al., 2010), 100-500 respondents which are considered sufficient to represent the population. Furthermore, Hair et al (2010) stated that the sample size can be used at least 5 or 10 times the number of indicators. In this study, the researcher used a sample size of 10 , and there are 22 indicators, 22 indicators x $10=220$. However, researcher completed the sample study of 300 respondents located in Indonesia to obtain the expected results and reduce errors during data processing and data analysis.

\section{Collecting Data Method}

The research was collected through a survey with a questionnaire instrument. The questionnaire given consisted of preliminary questions, namely "name, gender, age, latest education, profession, monthly expenses, length of time for using Shopee as a medium for online shopping, having made unplanned spontaneous purchases". Then the target question related to the variables studied, namely: statement of the dimension of ease of use; the perceived usefulness of the user belief variable which was adapted from research by (C. Hsu et al., 2016), wiillingness to buy which was adapted from research by (C. Hsu et al., 2012), flow experiences which were adapted from research by (C. Hsu et al., 2016; C. Hsu et al., 2012) and impulse buying or spontaneous buying behavior which was adapted from research by (C. Hsu et al., 2012); C. Hsu et al., 2016). The scale used in this study is the 5-point Likert scale which shows (one) as strongly disagree and 5 (five) as strongly agree (Sekaran, 2013). 


\section{Testing Method}

\section{Validity Test and Reliability Test}

After collecting the research data, researcher processed the data by using the SPSS version 21 for a windows software program. For the validity test by using face validity to see the contents of the instrument. Content validity assesses the relationship between items assessed based on experts' opinions. PEARSON was used for the validity test. The basis for using PEARSON's validity test is by comparing the r-count value and the r-table value and seeing the significance value(Sig.). If the value of r-count $>r$-table, it means that the item used in the questionnaire is valid, on the other hand, if the value of r-count $<r$-table, it means that the item in the questionnaire used is invalid. To find the r-table value with the number of respondents $(\mathrm{N})$ of 300 is at $5 \%$ significance in the distribution of the r-table statistical value, and the r-table value is 0.112 . Then, to find the significance (Sig.), if the resulting significance value $<0.05$, it means that the item is valid, on the other hand, if the significance value of Sig > 0.05, it means that the item is invalid (Ghozali, 2011).

The second validity test was conducted to see the construct validity which is the convergent validity (Neuman, 2013). Convergent validity was done by using confirmatory factor analysis (CFA) with the help of SPSS version 21 for windows. In measuring the level of relationship between variables and the feasibility of this factor analysis, the Kaiser-Meyer-Olkin Measure of Sampling Adequacy (KMO MSA) and Bartlett's Test was used, which is very useful for knowing the feasibility of a variable, whether it can be further processed using the factor analysis technique or not. The data was used by looking at the KMO MSA value above or greater than 0.5 .

As for reliability testing, it was done to see the extent to which measuring instruments can provide consistent results if measurements are made with the questionnaire that was used repeatedly. The basis for taking the reliability test was by using the Cronbach's alpha coefficient value and the rule of thumb must be greater than 0.7 although the value of 0.6 is still acceptable and was used for analysis (Hair et al., 2010).

\section{Multiple Linear Regression Analysis}

The analysis tool used to test the hypothesis was multiple regression analysis by testing the significance of the regression coefficient. This analysis is used if the dependent variable and the independent variable are matrices in nature, all variables must be interval or ratio variables (Cooper and Schindler, 2014). To test the research hypothesis using multiple linear regression analysis, the following equation was used:

$$
S Y=a+b_{1} X_{1}+b_{2} X_{2}+\varepsilon
$$

Information:

$\boldsymbol{S Y}=$ dependent variable, $\mathrm{a}=$ constant $, \mathrm{b} 1, \mathrm{~b} 2, \mathrm{~b} 3=$ regression coefficient, $\mathrm{X} 1, \mathrm{X} 2=$ independent variable, $\mathbf{\varepsilon}=$ error of term.

Hypothesis testing with multiple linear regression analysis is done by testing the accuracy of the regression function in estimating the actual value, which can be measured and assessed by Goodness of Fit and by testing the significance level of the regression 
coefficient. The hypothesis according to (Ghozali, 2011) is proven to be true if it meets the test:

The coefficient of determination $\left(\mathrm{R}^{2}\right)$

Simultaneous Significance Test (F Test Statistic)

Significant Test for Individual Parameters (t Statistical Test ).

\section{Research Model}

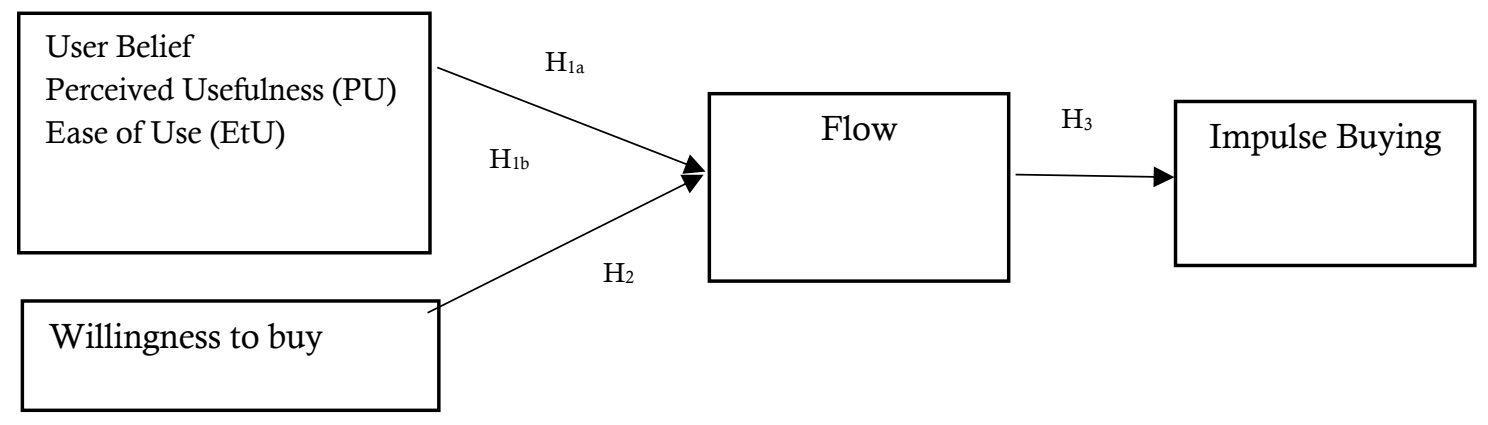

Figure 2. Thinking Framework Adapted from research by (C. Hsu et al., 2012; C. Hsu et al., 2016; Lee \& Wu, 2017)

\section{FINDING AND DISCUSSION}

The online survey obtained 355 responses from respondents' answers. From this data, only 271 data was used and processed with female respondents of $87 \%$ and male respondents of $12.9 \%$. Most of the respondents were between the ages of 18-27 and the average of latest education was at the bachelor's level. Most of the respondents' profession are students with monthly expenses of around Rp1,000,001-Rp2,500,000. More than $50 \%$ of respondents have used Shopee for more than 1-3 years, and most respondents make unplanned spontaneous purchases on clothing products by $71.2 \%$. The grouping of respondent profiles can be seen in Table 2 .

\section{Validity and Reliability Test Results}

After data collection was done, researcher then processed the data starting with testing the validity. The first thing to do was to input the data or tabulate data into SPSS, the data was named according to the items in each variable. In distributing the questionnaire, 355 data were collected from respondents, but only 271 data was used in the study for further analysis. Thus, the r-tabel value with the number of respondents $(\mathrm{N})$ of 271 is at $5 \%$ significance in the distribution of the statistical $r$-table value, the r-table value is 0.118 , and due to the resulting significance value $<0.005$, it means that the item is valid (Ghozali, 2011). 
Jurnal Economia, 17(2), October 2021, 175-194

Table 2. Characteristics of Respondents

\begin{tabular}{|c|c|c|c|}
\hline Characteristics & Information & Amount & Percentage \\
\hline \multirow[t]{2}{*}{ Gender } & Male & 35 & $12.9 \%$ \\
\hline & Female & 236 & $87.1 \%$ \\
\hline \multirow[t]{4}{*}{ Age } & $18-27$ years & 131 & $48.3 \%$ \\
\hline & $28-37$ years & 123 & $45.4 \%$ \\
\hline & $38-47$ years & 12 & $4.4 \%$ \\
\hline & $>47$ years & 5 & $1.8 \%$ \\
\hline \multirow[t]{5}{*}{ Last education } & High School/equivalent & 63 & $23.2 \%$ \\
\hline & Diploma & 20 & $7.4 \%$ \\
\hline & Bachelor's degree & 130 & $48.0 \%$ \\
\hline & Masters (2) & 56 & $20.7 \%$ \\
\hline & Doctorate (S3) & 2 & $0.7 \%$ \\
\hline \multirow[t]{6}{*}{ Profession } & Student & 73 & $26.9 \%$ \\
\hline & PNS/BUMN & 37 & $13.7 \%$ \\
\hline & Private employees & 64 & $23.6 \%$ \\
\hline & Entrepreneur & 21 & $7.7 \%$ \\
\hline & $\begin{array}{l}\text { Professionals (accountants, } \\
\text { consultants, lawyers, lecturers, etc.) }\end{array}$ & 40 & $14.7 \%$ \\
\hline & Others (Housewives, Teachers) & 36 & $13.3 \%$ \\
\hline Expenditures per & $<\mathrm{Rp} 1,000,000$ & 64 & $23.6 \%$ \\
\hline \multirow[t]{4}{*}{ month } & $\mathrm{Rp} 1,000,001$ - Rp2,500,000 & 97 & $35.8 \%$ \\
\hline & $R p 2,500,001-R p 3,500,000$ & 36 & $13.3 \%$ \\
\hline & $\mathrm{Rp} 3,500,001-\mathrm{Rp} 5,000,000$ & 29 & $10.7 \%$ \\
\hline & $>\mathrm{Rp} 5,000,001$ & 45 & $16.6 \%$ \\
\hline Use of the Shopee & $<1$ year & 46 & $17.0 \%$ \\
\hline Digital & 1-3 years & 157 & $57.9 \%$ \\
\hline Application & $>3$ years & 68 & $25.1 \%$ \\
\hline \multirow{2}{*}{ Shopee App users } & Yes & 325 & $91.5 \%$ \\
\hline & No & 30 & $8.5 \%$ \\
\hline \multirow[t]{10}{*}{ Purchased items } & Clothes & 193 & $71.2 \%$ \\
\hline & Electronic goods & 72 & $26.6 \%$ \\
\hline & Food & 52 & $19.2 \%$ \\
\hline & Cosmetics & 126 & $46.5 \%$ \\
\hline & Footwear (sandals/shoes) & 65 & $24 \%$ \\
\hline & Accessories & 101 & $37.3 \%$ \\
\hline & Beverages & 9 & $3.3 \%$ \\
\hline & Stationary & 31 & $11.4 \%$ \\
\hline & Home appliances & 111 & $41 \%$ \\
\hline & Others. & 30 & $11.7 \%$ \\
\hline
\end{tabular}


Table 3. Pearson's Validity Test Results with Bivariate Correlation

\begin{tabular}{lll}
\hline Item of variabel & Total_of Item & $\begin{array}{l}\text { Significance } \\
\text { (Sig.) }\end{array}$ \\
\hline PU1 & 0.844 & 0.000 \\
PU2 & 0.884 & 0.000 \\
PU3 & 0.826 & 0.000 \\
PU4 & 0.707 & 0.000 \\
\hline EtU1 & 0.819 & 0.000 \\
EtU2 & 0.864 & 0.000 \\
EtU3 & 0.846 & 0.000 \\
EtU4 & 0.862 & 0.000 \\
\hline WtB1 & 0.806 & 0.000 \\
WtB2 & 0.837 & 0.000 \\
WtB2 & 0.854 & 0.000 \\
\hline FE1 & 0.635 & 0.000 \\
FE2 & 0.700 & 0.000 \\
FE3 & 0.714 & 0.000 \\
FE4 & 0.671 & 0.000 \\
\hline IBB1 & 0.747 & 0.000 \\
IBB2 & 0.809 & 0.000 \\
IBB3 & 0.861 & 0.000 \\
IBB4 & 0.841 & 0.000 \\
IBB5 & 0.803 & 0.000 \\
\hline
\end{tabular}

From Table 3 above, the results of Pearson's validity test with bivariate correlation shows that for the $\mathrm{PU}, \mathrm{EtU}, \mathrm{WtB}$, and IBB constructs, the calculated $\mathrm{r}$ values are all greater than the r-table value, it can be concluded that the statement items or indicators used are deemed valid. However, differs from the FE construct, flow experience, only FE1-FE4 items have a calculated $\mathrm{r}$-value of more than $\mathrm{r}$ table, for items FE5 and FE6 were eliminated because the calculated $r$-value of the items weresmaller than the $r$ table value. Thus , the two items cannot be used for further analysis.

Furthermore,the validity test was carried out by using the varimax method with Kaiser normalization in Confirmatory Factor Analysis (CFA) with the help of SPSS version 21.0 for windows software and the KMO test was carried out to measure the level of intercorrelation between variables and whether or not factor analysis was possible. The desired $\mathrm{KMO}$ value must be greater than (>) 0.5 and the probability value on the Bartlett test is less than $(<) 0.005$. Thus, it can be concluded that the measuring instrument used in the study is considered valid and the factor analysis test can be continued (Ghozali, 2011).

Requirements for the KMO MSA and Bartlett's Test values that must be obtained are at least greater than (>) 0.7. The results of data processing carried out in Table 4 show that the KMO MSA and Bartlett's Test values are 0.749 with a significance level of 0.000 more than $>0.005$, so that factor analysis can then be carried out. 
Table 4. KMO and Bartlett's Test Results

\begin{tabular}{lcl}
\hline Kaiser-Meyer-Olkin Measure of Sampling Adequacy. & 0.749 \\
& Approx. Chi-Square & 1932.340 \\
Bartlett's Test of Sphericity & df & 231 \\
& Sig. & .000 \\
\hline
\end{tabular}

Table5. Rotated Component Matrix Validity Test Results

\begin{tabular}{|c|c|c|c|c|c|}
\hline \multirow[t]{2}{*}{ Item } & \multicolumn{5}{|c|}{ Component } \\
\hline & 1 & 2 & 3 & 4 & 5 \\
\hline PU1 & & & .827 & & \\
\hline PU2 & & & .865 & & \\
\hline PU3 & & & .804 & & \\
\hline PU4 & & & .667 & & \\
\hline EtU1 & .776 & & & & \\
\hline EtU2 & .856 & & & & \\
\hline EtU3 & .813 & & & & \\
\hline EtU4 & .875 & & & & \\
\hline WtB1 & & & & .854 & \\
\hline WtB2 & & & & .734 & \\
\hline WtB2 & & & & .772 & \\
\hline FE1 & & & & & .554 \\
\hline FE2 & & & & & .574 \\
\hline FE3 & & & & & .766 \\
\hline FE4 & & & & & .782 \\
\hline IBB1 & & .621 & & & \\
\hline IBB2 & & .737 & & & \\
\hline IBB3 & & .817 & & & \\
\hline IBB4 & & .818 & & & \\
\hline IBB5 & & .703 & & & \\
\hline
\end{tabular}

Based on the results of data processing on the Pearson's validity test by conducting bivariate correlation, two items were eliminated because the calculated r-value was below the $\mathrm{r}$ table. Then in the test of factor analysis in Table 5, the rotated component matrix shows that two items were eliminated because they do not group the components that should be measured on items of a constructThose two items were the experience flow variable (FE5 and FE 6).

The variable dimension of perceived usefulness (PU) from user belief results wer grouped into factor 3 or component 3 (PU1, PU2, PU3, PU4). Then the dimension of ease of use (EtU) of the user belief results wer grouped into factor 1 or component 1 is (EtU1, EtU2, EtU3, EtU4). The willingness to buy variable results were grouped into factor 4 or 
component 4 (WtB1, WtB2, WtB3). The flow experience variable (FE) results were grouped into factor 5 or component 5 (FE1, FE2, FE3, FE4). Lastly, the unplanned impulse buying behavior (IBB) variable results were grouped into factor 2 or component 2(IBB1, IBB2, IBB3, IBB4, IBB5). To make it easier, researcher summarizes several statement items, that in all variables only the flow experience variable that had its statement item eliminated, the FE 5 and FE 6.

Table 6. Reliability Test Results

\begin{tabular}{|c|c|c|c|c|c|}
\hline No & Variable & $\begin{array}{l}\text { Cronbach's } \\
\text { Alpha }\end{array}$ & $\begin{array}{l}\text { Corrected } \\
\text { Correlation }\end{array}$ & Item-Total & Information \\
\hline \multirow[t]{6}{*}{1} & Perceived & 0.834 & & & Reliable \\
\hline & Usefulness (PU) & & & & \\
\hline & PU1 & & 0.705 & & \\
\hline & PU2 & & 0.769 & & \\
\hline & PU3 & & 0.672 & & \\
\hline & PU4 & & 0.519 & & \\
\hline \multirow[t]{5}{*}{2} & Ease of Use (EtU) & 0.868 & & & Reliable \\
\hline & EtU1 & & 0.675 & & \\
\hline & EtU2 & & 0.751 & & \\
\hline & EtU3 & & 0.701 & & \\
\hline & EtU4 & & 0.759 & & \\
\hline \multirow[t]{4}{*}{3} & $\begin{array}{l}\text { Willingness to Buy } \\
\text { (WtB) }\end{array}$ & 0.776 & & & Reliable \\
\hline & WtB1 & & 0.601 & & \\
\hline & WtB2 & & 0.595 & & \\
\hline & WtB3 & & 0.649 & & \\
\hline \multirow[t]{6}{*}{4} & Flow & 0.683 & & & Reliable \\
\hline & Experience (FE) & & & & \\
\hline & FE1 & & 0.446 & & \\
\hline & FE2 & & 0.483 & & \\
\hline & FE3 & & 0.563 & & \\
\hline & FE4 & & 0.393 & & \\
\hline \multirow[t]{8}{*}{5} & Impulse & 0.871 & & & Reliable \\
\hline & Buying Behavior (IB & & & & \\
\hline & B) & & & & \\
\hline & IBB1 & & 0.603 & & \\
\hline & IBB2 & & 0.686 & & \\
\hline & IBB3 & & 0.767 & & \\
\hline & IBB4 & & 0.739 & & \\
\hline & IBB5 & & 0.694 & & \\
\hline
\end{tabular}




\section{Reliability Test Results}

Whereas the results of the reliability test were carried out by putting items in each of these variables. The instrument or statement item is considered consistent or reliable if the value of the Cronbach's alpha coefficient and the rule of thumb $>0.7$, although, the value of 0.6 is still acceptable and used for further analysis (Hair et al., 2010). Reliability testing was also carried out using the help of SPSS for windows version 21 software. The following is a table of 6 processed reliability test results.

Based on Table 6 above, a reliability test has been carried out and shows that all items of these variables obtained a Cronbach's Alpha value of $>0.7$, although one flow experience variable has a Cronbach's Alpha value of 0.6, it is still acceptable. This means that the statement instrument used is considered reliable or reliable for each indicator. Thus, the items in this statement can be used as a research instrument for further analysis. Some items have $a$ Cronbach's Alpha value of 0.834 , which means that this value meets the least requirements of the Cronbach's Alpha value that is $>0.7$, meaning that the test results are considered to have good reliability if further analysis is used.

\section{Multiple Regression Analysis Test Results}

The purpose of hypothesis testing is to examine the effect of the perceived usefulness variable dimension and the ease of use of the user belief variable on the flow experience; testing the effect of willingness to buy on flow experience and testing flow experience variable on impulse buying behavior. Researcher used multiple linear regression analysis to examine the influence between two or more independent variables on the dependent variable. Testing was done by using SPSS version 21 software in Table 7 shown below.

Table 7. Multiple Regression Analysis Results

\begin{tabular}{|c|c|c|c|c|c|c|c|}
\hline Hypothesis & $\begin{array}{l}\text { Independent } \\
\text { variable }\end{array}$ & $\begin{array}{l}\text { Dependent } \\
\text { variable }\end{array}$ & Predictions & $\begin{array}{l}\text { Beta } \\
\text { Coefficient }\end{array}$ & $\begin{array}{l}\text { t- } \\
\text { value }\end{array}$ & Sig. & Information \\
\hline H1a & $\begin{array}{l}\text { User Belief } \\
\text { (perceived }\end{array}$ & $\begin{array}{l}\text { Experience } \\
\text { flow }\end{array}$ & Positive & 0.212 & 3.346 & 0.001 & Supported \\
\hline $\mathrm{H} 1 \mathrm{~b}$ & $\begin{array}{l}\text { usefulness) } \\
\text { (ease to use) }\end{array}$ & $\begin{array}{l}\text { Experience } \\
\text { flow }\end{array}$ & Negative & 0.094 & 1.404 & 0.161 & $\begin{array}{l}\text { Not } \\
\text { Supported }\end{array}$ \\
\hline $\mathrm{H} 2$ & $\begin{array}{l}\text { Willingness } \\
\text { to buy }\end{array}$ & $\begin{array}{l}\text { Experience } \\
\text { flow }\end{array}$ & Positive & 0.478 & 7.625 & 0.000 & Supported \\
\hline \multicolumn{8}{|c|}{$\mathrm{R}^{2}=0.502$, Adjusted $\mathrm{R}^{2}=0.496, \mathrm{~F}$-test $=89.631$, Sig. $=0.000$} \\
\hline H3 & $\begin{array}{l}\text { Experience f } \\
\text { low }\end{array}$ & $\begin{array}{l}\text { Impulse } \\
\text { Buying } \\
\text { Behavior }\end{array}$ & Positive & 0.378 & 6.701 & 0.000 & Supported \\
\hline
\end{tabular}

From the look of SPSS output magnitude adjusted $\mathrm{R}^{2}$ was 0.496 , meaning $49.6 \%$ variable of flow experience can be explained by the variable dimensions of the three independent variables, perceived usefulness, ease of use of the user belief, and 
variable willingness to buy. While the rest $(100 \%-49.6 \%=50.4 \%)$ can be explained by other causes outside the model or other factors that have not been examined in this study.

From the results of the multiple regression analysis tests in Table 7, the F statistical test shows whether all the independent variables that are included or used in the model have a joint influence on the dependent variable. The results of the $\mathrm{F}$ test obtained the calculated $F$ value of 89.631 with a probability of 0.000 . This means that the probability is much smaller than 0.05 , so the multiple regression model can be used to predict flow experience or it can be said that the perceived usefulness, ease of use, and willingness to buy together affected flow experience.

Out of the three independent variables that were entered and used in the regression model, the ease of use variable from the user belief dimension was not significant, this can be seen from the significance probability for the user belief dimension variable of 0.161 , which means that it was far above 0.05. Meanwhile, the dimension of the perceived usefulness of user belief and willingness to buy are significant at 0.001 and 0.000 below 0.05. From this, it can be concluded that the flow experience variable is influenced by the user belief dimension variable, namely the perceived usefulness variable, and willingness to buy.

Furthermore, as for the display output of SPSS in Table 8, the amount of $\mathrm{R}^{2}$ is 0.143 , this means that only $14.3 \%$ of the variable behavior of impulse buying can be explained by flow experience. While the rest $(100 \%-14.3 \%=85.7 \%)$ can be explained by other factors that were not examined in this study or by other causes outside of this model.

From the results of the multiple regression analysis tests in Table 8 , the F statistical test shows whether all the independent variables that were included or used in the model have a joint influence on the dependent variable. The results of the $\mathrm{F}$ test obtained the calculated $F$ value of 44.907 with a probability of 0.000 . This means that the probability is much smaller than 0.05 , thus, the multiple regression model can be used to predict impulse buying behavior or it can be said that flow experience simultaneously affected impulse buying behavior.

The independent variable that were entered and used in the regression model, flow experience variable, showed a significant value. This can be seen from the significance probability for flow experience variable of 0.000 , this means that it was far above 0.05 . From the regression results, it can be concluded that the willingness to buy variable was influenced by flow experience variable.

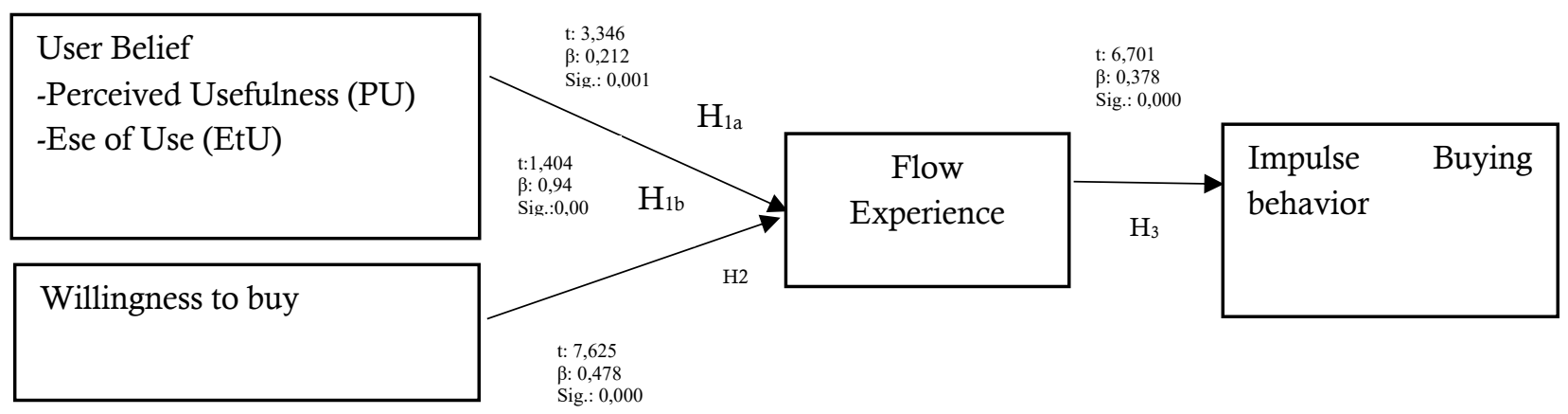

Figure 3. Testing Model and Multiple Regression Analysis Test Results 
Figure 3 shows the significance of the influence of the constructs on the research's framework model. It can be seen that the variable dimension of the perceived usefulness of user belief variable has a calculated $t$ value of 3.346 and a beta of 0.212 . Likewise, the willingness to buy variable has a calculated $t$ value of 7.625 and a beta of 0.478 . Whereas, for the dimension of ease of use variable from user belief has no significance with other constructs, the calculated t statistical value of 1.404 and beta 0.94 . The latter shows the significance of flow experience variable on impulse buying behavior with a calculated $t$ statistical value of 6.701 with a beta of 0.378 and all of them have a significance level below 0.05 .

\section{Discussion}

The results of the factor analysis validity test in Table 5 show that all items of a variable that are on loading factor are values above ( $>$ ) 0.5 . This method was done not only by eliminating items that are considered to be of bad value, but also by eliminating outliers that might damage the results of the research, by looking for extreme data that is far from the average by making the mean first using the average to produce the average extreme value. Some extreme data or outliers were found, so researcher had to eliminate it to get a better value. After that, it was tested again and the loading factor value was above 0.5 and was grouped into each variable. This shows that the items used are valid and can be used for the next stage of analysis.

Based on the results of multiple regression analysis tests carried out, it shows that the perceived usefulness dimension variable of user belief variable has a positive and significant effect on flow experience (H1a). On the contrary, the ease of use dimension of user belief variable has no positive effect on flow experience. The results obtained in hypothesis 1 are consistent, appropriate and have been confirmed by previous researches conducted by (C. Hsu et al., 2016), (Zhou et al., 2010), and (Nata \& Sukaris, 2018), but this research is conducted using different sample sizes, research objects and different countries for the dimension of ease of use variable from user belief variable were not as basic and unconfirmed as previous researches by (C. L. Hsu, Wu, \& Chen, 2013), (C. Hsu et al., 2016), and (H. Chang \& Wang, 2008).

The positive and significant influence of $\mathrm{H} 1$ and the negative influence of $\mathrm{H} 1 \mathrm{~b}$ show that there is an increase in confidence of the benefits felt by consumers or users of Shopee in online shopping to create comfortable conditions when using it because they are always exposed to the promotions or advertisements offered in it so that consumers carried away by this situation, coupled with the flexibility in using Shopee, users can access and open it anytime and anywhere. However, user confidence in the ease of using Shopee is different. Researcher suspects the lack of increased confidence in the ease of using Shopee so that users are less able to feel the flow of experience of exploring Shopee, even though they are exposed to online marketing or promotions provided, Shopee users choose to reduce the searching time for any information as it confused them.

Furthermore, the test results of multiple regression analysis indicate that the willingness to buy variable has a positive and significant effect on the flow experience (H2). 
Likewise, in hypothesis 3 , the flow experience variable has a positive and significant effect. As described above, the willingness to buy variable is consistent and in accordance with the research by (C. Hsu et al., 2012), although the research did not directly test this effect, the willingness to buy variable became a moderator variable to connect indirectly between the flow experience and impulse buying behavior. The results of moderation in the study by (C. Hsu et al., 2012) stated that when willingness to buy is low, high flow experiences will require lower impulse buying than low flow experiences coupled with a high level of willingness to buy. Then, researcher tried to test the willingness to buy variable to the flow experience simultaneously and the results were significantly positive. These results explain that when a consumer or user has the desire to buy a product in Shopee but does not yet know what product to buy, it will encourage them to search for information and explore Shopee so that they will be exposed to information and promotional advertisements shown, then hypothesis 2 is supported.

The results of multiple regression analysis show positive and significant influence of flow experience on impulse buying behavior (H3). These results are consistent and in accordance with researches by (C. Hsu et al., 2016) and (C. Hsu et al., 2012). Increasing flow experience in which someone is exploring Shopee with the overall experience sensations perceived by the user is a total involvement in Shopee. The increase influences a person's attitude and shape the impulse buying behavior.

This study proves that the dimension of the perceived usefulness of the user belief variable has a positive effect on flow experience. Willingness to buy proves that there is a positive influence on flow experience, and flow experience proves that there is a positive influence on impulse buying behavior. However, the results of the ease of use dimension of the user belief variable do not prove a positive effect on flow experience.

Several respondents made unplanned spontaneous purchases, such as for clothes. Clothing in this case often makes someone impulse-buying because it offers cheap prices, gives discounts, and free shipping throughout Indonesia. Besides, not only provides information about products sold in it, but Shopee also facilitates its users with interesting in-app games, with coins as the reward that can be used to reduce the cost of purchased goods. Therefore, Shoppe as an online shopping place must focus on the perceived useful factors to increase and build user trust in it and make people interested in purchasing or willingness to buy. Besides, users do not hesitate to explore to get a full thrill experience when they are in total engagement with Shopee.

\section{CONCLUSION}

This study aims to prove a empirical hypothesis, by testing the variable dimension of the perceived usefulness of the user belief variable (user trust), it underlies users to explore and get a pleasant sensation when diving in it. From the results of hypothesis testing conducted, it is found that hypothesis 1a, hypothesis 2 , and hypothesis 3 are supported. Meanwhile, hypothesis $1 \mathrm{~b}$ was found not supported by the affected variables.

The limitation of this study is that it uses 22 question items out of 5 variables, researcher thinks that the number of statement items used is very small, thus, the results 
are not very good. Future studies, consider using a research instrument of more than 22 statements to get good results. The research time is a cross-section which is the type of research observed the data population or samples only once at the same time.

Future studies are advised to use a longitudinal type of study to compare changes in study subjects after a certain period. There are very limited researches that discuss the willingness to buy a variable as an independent variable to see its effect on flow experience. So that researcher had difficulties in explaining the concept. For further research, it is necessary to add variables of browsing activity, hedonic, utilitarian, and website quality to get better results and understanding to strengthen the relationship of these variables. This research is limited to users of Shopee only, therefore further researches are advised to add other digital applications to be more diverse and easier to compare and add a larger number of respondents to get better results, for example, the digital platforms such as Tokopedia, Jd.id, and others.

\section{REFERENCES}

Chang, H., \& Wang, I. C. (2008). An investigation of user communication behavior in computer mediated environments. Computers in Human Behavior, 24(5), 2336-2356. https://doi.org/10.1016/j.chb.2008.01.001

Chang, M. K., Cheung, W., \& Tang, M. (2013). Building trust online: Interactions among trust building mechanisms. Information and Management, 50(7), 439-445. https://doi.org/10.1016/j.im.2013.06.003

Cooper, D.R, and Schindler, P.S. 2014. Business Research Method. New York: McGrawHill, 12 th edition.

Csikszentmihalyi, M. (1975). Play and Intrinsic Rewards. Joumal of Humanistic Psychology, 15(3), 41-63.

Eka, R. 2018. Lanskap E-commerce di Indonesia dari Perspektif Konsumen https://dailysocial.id/post/e-ecommerce-di-indonesia accessed on April 21, 2019.

Ghozali, Imam. 2011. Aplikasi Analisis Multivariate dengan Program IBM SPSS 19. Edisi 5, Badan Penerbit Universitas Diponegoro.

Hair, J. F, Back, W. C, Babin, B. J, and Anderson, R. E. 2010. Multivariate data analysis. (7th ed.). New Jersey: Pearson Education Inc.

Ho, L., Kuo, T., \& Lin, B. (2012). Computers in Human Behavior The mediating effect of website quality on Internet searching behavior. Computers in Human Behavior Journal, 28, 840-848. https://doi.org/10.1016/j.chb.2011.11.024

Hsu, C., Chang, K.-C., Kuo, N.-T., \& Cheng, Y. S. (2016). The mediating effect of flow experience on social shopping behavior. Information Development, 1-14. https://doi.org/10.1177/0266666916651918 
Hsu, C., Chang, K., \& Chen, M. (2012). Flow Experience and Internet Shopping Behavior: Investigating the Moderating Effect of Consumer Characteristics. Systems Research and Behavioral Science, 29, 317-332. https://doi.org/10.1002/sres

Hsu, C. L., Chang, K. C., Kuo, N. Te, \& Cheng, Y. S. (2016). The mediating effect of flow experience on social shopping behavior. Information Development, 1-14. https://doi.org/10.1177/0266666916651918

Hsu, C. L., Wu, C. C., \& Chen, M. C. (2013). An empirical analysis of the antecedents of e-satisfaction and e-loyalty: Focusing on the role of flow and its antecedents. Information Systems and E-Business Management, 11(2), 287-311. https://doi.org/10.1007/s10257-012-0194-8

Koufaris, M. (2002). Applying the Technology Acceptance Model and Flow Theory to Cyworld User Behavior. Information Systems Research, 13(2), 205-223. https://doi.org/10.1089/cpb.2007.0117

Lee, C.-H., \& Wu, J. J. (2017). Consumer online flow experience. Industrial Management \& Data Systems, 117(10), 2452-2467. https://doi.org/10.1108/imds-11-2016-0500

Nata, J. H., \& Sukaris, S. (2018). Mobile Display Advertising Pengaruh Aktivitas Browsing, Flow, Dan Kepercayaan Online Terhadap Niat Pembelian Barang-Barang Terbaru Di Instagram (Studi Pada Follower Akun Instagram Kategori Produk Fashion, Gadget, dan Kuliner di Surabaya). INOBIS: Jurnal Inovasi Bisnis Dan Manajemen Indonesia, 2(1), 16-30. https://doi.org/10.31842/jurnal-inobis.v2i1.58

Neuman, W. Lawrence 2013. Metode Penelitian Sosials: Pendekatan Kualitatif dan Kuantitatif, Edisi 7. Jakarta: PT Indeks.

Novak, T. P., \& Hoffman, D. L. (1996). Marketing in Hypermedia Computer-Mediated Environments: Conceptual Foundations. Journal of Marketing, 60(3), 50-68.

Ozkara, B. Y., Ozmen, M., \& Kim, J. W. (2017). approach to the fl ow theory based on hedonic and utilitarian value. Journal of Retailing and Consumer Services, 37(February), 119-131. https://doi.org/10.1016/j.jretconser.2017.04.001

Pangestika, W. 2018. Mengenal digital marketing konsep dan penerapannya. https://www.jurnal.id/id/blog, accessed on April 21, 2019.

Richard, M., Chebat, J., Yang, Z., \& Putrevu, S. (2010). A proposed model of online consumer behavior: Assessing the role of gender. Journal of Business Research, 63(9-10), 926-934. https://doi.org/10.1016/j.jbusres.2009.02.027

Sekaran, U. dan Bougie, R. 2013. Research methods for business: a skill -building approach. (6th ed). Wiley: United Kingdom.

Stern, H. (1962). The Significance of Impulse Buying Today. Journal of Marketing, 26(2), 59-62. https://doi.org/10.1177/002224296202600212

Sundstrom, M., Balkow, J., Florhed, J., Tjernstrom, M., \& Wadenfors, P. (2013). Inpulsive Buying Behaviour: The Role of Feelings When Shopping for Online 
Fashion. Swedish Institute for Innovative Retailing, School of Business and IT, Allegatan, (July), 1-22.

Wang, Y. J., Hernandez, M. D., \& Minor, M. S. (2010). Web aesthetics effects on perceived online service quality and satisfaction in an e-tail environment: The moderating role of purchase task. Journal of Business Research, 63(9-10), 935-942. https://doi.org/10.1016/j.jbusres.2009.01.016

Wei, W. J., Ma, Z. J., \& Chen, Y. W. (2017). Empirical study of the relationship between flow experience, perceived transaction value and impulse buying behavior. IEEE International Conference on Industrial Engineering and Engineering Management, 2017Decem, 2246-2250. https://doi.org/10.1109/IEEM.2017.8290291

Yusra dan Yenny. 2018. Mengungkap layanan e-commerce terpopuler di Indonesia. Https://www.dailysocial.id accessed on October 21, 2019.

Zhou, T. (2012). Examining mobile banking user adoption from the perspectives of trust and flow experience. Information Technology and Management, 13(1), 27-37. https://doi.org/10.1007/s10799-011-0111-8

Zhou, T., Li, H., \& Liu, Y. (2010). The effect of flow experience on mobile SNS users' loyalty. Industrial Management and Data Systems, 110(6), 930-946. https://doi.org/10.1108/02635571011055126 